\title{
Islam/ISm and Democracy: Past the Compatibility Problem and Towards the Post-Islamist Turn
}

\author{
Matthew J. Gordner, University of Alberta
}

\begin{abstract}
This article addresses of some the shortcomings in the literature on "Islam/ism and democracy" that result from questioning whether Islam/ism and democracy are compatible. I argue, contrary to the compatibility paradigm, that what is important is how Muslims believe in and practice democracy. I examine "post-Islamist" discourses and politics as potential democratizing movements that support an admixture of rights-based claims and Islamic legitimacy. In light of recent popular uprisings in Yemen and Egypt that have followed from the successful ouster of the Ben Ali regime in Tunisia, this article highlights the democratic attitudes throughout the Muslim majority states and the Middle East in particular. I conclude that despite fears of Islamist accessions to power, Islamist participation should be invited as a method of cultivating and furthering democratic political cultures in the Middle East and throughout Muslim majority states.
\end{abstract}

The topic of Islam/ism and democracy is mired in debate over whether Islam is compatible with democracy. Those who seek to demonstrate the compatibility of Islam and democracy argue that Islamic texts and traditions, Qur'anic injunctions, and sites of Muslim history provide sound examples and promising sites for the foundation and founding of Muslim democracy. On the other hand, skeptics argue that Islam is inherently incompatible with democracy owing to a number of interrelated features of Muslims' histories, politics, and cultures: the unequal relationship between 
men and women, minorities, and non-Muslims; the paucity of historical literature that provides for the transparent and accountable functioning of the modern state system and its relationship to civil society; and the absence of basic freedom and equality otherwise required of civil society in order for pluralism and democracy to thrive.

To one degree or another, both of these lines of argument are flawed. In their attempts to prove the compatibility of Islam/ism and democracy, many interlocutors are overly optimistic about the ways in which Muslim texts and traditions provide for democratic-type practice throughout Islamic history. Moreover, they overestimate the extent to which stated examples-Muhammad employing the advice of his most trusted companions as a site of consensus, for one-may be translated into inclusive procedural democracy. Finally, skeptics are correct in identifying the relative absence of democracies throughout Muslim majority countries compared with non-Muslim majority countries, let alone the democratic deficit of the Middle East in particular. For the most part, the skeptics argue, authoritarianism is the rule and democracy is the exception: from where will a democratic ethos arise?

Arguments for the incompatibility of Islam/ism and democracy are also misled. The factors that skeptics identify as inhibitive to democratic practice, namely the traditions and cultures of Muslims, rely on monolithic and essentialist constructions of Islam, among other sweeping generalizations about what all Muslims believe. Interlocutors seeking to prove the incompatibility of Islam/ism and democracy thus do not heed the multiplicity of Muslims who "speak for" Islam. Furthermore, what this negativistic camp of scholars conceives of as democracy is often constructed along ethnocentric, Western liberal conceptions. Whether in a procedural sense, by which elections and ballot boxes are taken as the only form of democratic practice, or else by some substantive conception wherein individualism and capitalism, free markets and post-industrialization are taken as the only workable catalysts to the formation of democratic political culture, democracy in this narrow sense is denied its full application as "rue of the people" or "freedom and equality," as it is differently understood within and across cultures.

In this article I address some of these shortcomings in the literature on Islam/ism and democracy. I argue, contrary to the paradigm 


\section{Islam/ism and Democracy}

that begins by asserting the (in)compatibility of Islam/ism and democracy, that what is important is not whether they are compatible but how Muslims believe in and practice democracy. Thus, in light of democratic attitudes throughout the Muslim world, and the Middle East in particular, I argue that despite fears of Islamist accessions to power, Islamist participation should be invited as a method of cultivating and furthering democratic political cultures in the Middle East and elsewhere. Although Western governments often maintain the notion that "it is better to support the authoritarian you know than the Islamist you do not," this mantra is shortsighted and bound to fail to provide for any lasting or indigenous democratic ethos within Muslim-majority states and societies. Indeed, recent outrage in Tunisia, Egypt, and Yemen over unaccountable government and arbitrary rule suggests that longtime yearnings for greater equalities, rights, and freedoms for many demos in waiting are on the horizon. A subsidiary thesis is that security and stability are no longer tenable reasons for which to support authoritarians. Western governments should move toward greater incentives to sustain meaningful democratic participation, including Islamist democratic participation. This is especially the case given the likely ascendancy of a "post-Islamist" discourse and politics, a fusion of rights-based claims and Islamic legitimacy-a movement that is capable of supporting democratization from below that should not go unnoticed.

\section{From Islamism to Post-Islamism}

There are many typologies ascribed to the various socio-political movements that draw inspiration or motivation from Islam. The effort on the part of Western scholarship to categorize Muslims as this or that persuasion is no doubt what has provided for the popularity of the "Islam as other" industry of scholarship prevalent in academic and popular literature on the history and politics of Islam and Muslimmajority states and societies over especially the last quarter century. Attempts to pigeonhole Muslims according to their supposed sociopolitical leanings, fidelities or affinities to Western liberal dictums, beliefs, and practices is more often than not used to demonstrate either a dissonance or harmony with the greater interests of recent neo-liberal and neo-conservative bents in Western governments and institutions. 
To this end, the adjective "Islamic" as it is applied across the board, whether to modernists, reformists, traditionalists, or terrorists, does little to clarify how Muslims behave or act. Indeed, reference to an "Islamic" variant of either violence or politics undoubtedly obscures more than it elucidates: there is nothing especially Islamic about any one kind of violence or politics. Thus, neither those who self-identify as, nor those who are identified as archetypically Muslim necessarily represent all or majority Muslim opinion. Though Muslims are pejoratively called Islamic fundamentalists, Islamists, jihadists, and/ or Islamic terrorists, all of these categories imply different things in different contexts. In many cases, they also differ depending on the author or institution that invokes them.

"Islamic fundamentalism" is somewhat of a misnomer. Fundamentalism "generally urges passive adherence to literal reading of scriptures and does not advocate change of the social order, instead focusing on reforming the lives of the individual and family." Fundamentalism takes its namesake from evangelical movements that emerged in the 1910s and became popular by the 1920s. Islamist movements create modern reinterpretations of old texts and scriptures, however, and are therefore not fundamentalist at all, because they do not take a literal, or "fundamental," interpretation of the Qur'an as the basis for their politics and ideologies. Islamist movements, unlike many evangelical fundamentalist movements, are modern readings of scripture. As such, Islamist interpretations are a product of, and at the same time a reaction to, modernity. The term Islamist is therefore more appropriately utilized in allusion to "a political perspective centrally informed by a set of religious interpretations and commitments." Islamism amounts to a wide array of political ideologies with varying commitments, political ideals, goals, and aspirations. Though these commitments and aspirations overlap sufficiently to render the Islamist moniker useful in some limited contexts, in most cases the comparisons and contrasts drawn between different sets of Islamists, modernists, Salafis, and 'ulama rather obfuscates the neat and clear cut analytical categories that Western scholarship seeks out in the first

1 Ali R. Abootalebi, "Islam, Islamists, and Democracy," Middle East Review of International Affairs 3, 1 (March, 1999). Last viewed on February 6, 2010 at http:// meria.idc.ac.il/journal/1999/issue1/jv3n1a2.html

2 Tamara Coffman Wittes, “Three Kinds of Movements," Journal of Democracy 19, 3(2008), 7. 


\section{Islam/ism and Democracy}

place. ${ }^{3}$ This, in turn, leads many Western scholars to find rather than reveal similarities or differences between these movements that are unfounded and misleading.

There are many disagreements over when "political Islam," or "Islamism" emerged, who qualifies as an "Islamist," and why. Academic literature is replete with divisions between moderate and radical Islamists. In common parlance, radical Islamists are said to seek out the imposition of the "sharia-tization" of the state on what amounts in practice to a mostly unwilling populace. Moderate Islamists, on the other hand, expound upon a more inclusive and progressive politics. Many of their conceptions of the state are "not theocratic but ideological" in that the "rights and duties of [their] citizens shall be determined by the extent to which they identify themselves with this ideology."

No consensus exists on what constitutes a moderate Islamist, let alone a progressive or liberal Muslim, either. For moderate Islamists, the shari'a is perhaps "not the appropriate vehicle for Islamic selfdetermination in the present context," as some have argued, because it is "not divine." Rather, since many moderate Islamists recognize that "it is the product of human interpretation of those sources," the sharia is considered a guiding symbolic doctrine rather than a concrete, narrowly interpreted set of rules and practices. ${ }^{5}$

Many scholars forge distinctions between those Islamists who employ terrorism and violence to attain their desired ends from those who do not, although likewise these distinctions are for the most part unhelpful. The term "jihadist" applies to a number of groups-alQaeda, Hezbollah, and Hamas among them-although many Islamist groups and political parties may or may not renounce violence, may or may not participate in the politics of the state, may or may not offer charitable and social services, and may or may not control an armed militia on the side at the same time. A further distinction exists

3 Roxanne L. Euben and Muhammad Qasim Zaman (eds), Princeton Readings in Islamist Thought (Princeton: Princeton University Press, 2009), 5-27.

4 Khalifa Abdul Hakim, "Islam and Democracy." Last viewed on February 6, 2010 at http://muslim-canada.org/ch19hakim.html. This article is a chapter from his book The Prophet and His Message (Lahore: Institute of Islamic Culture), 1987.

5 Abdullahi Ahmed An-Na'im, Toward an Islamic Reformation: Civil Liberties, Human Rights and International Law (Syracuse, NY: Syracuse University Press), 1990, 185. 
between those jihadists who target the "near enemy," or what they consider domestic regimes that are un-Islamic (reminiscent of alJihad and the assassination of then-Egyptian President Anwar Sadat), from those, like al-Qaeda, who are bent on destroying the "far enemy" in the name of jihad waged against "the West," principally in the form of U.S. imperialism. ${ }^{6}$

The inspiration, influence, and motivation that Muslims draw from modernists, Salafis, reformers, traditionalists, moderate, and radical Islamist theorists, inter alia, ${ }^{7}$ vary significantly. Categorizing one or another Muslim or group of Muslims as such should be considered a loose system at best, one that is grossly misused and mostly incapable of recognizing the different contents and contexts of Muslims' interpretations, theories, beliefs and practices.

Perhaps the most useful distinction for present purposes is a movement that Asef Bayat calls "post-Islamism." Fusing a rightsbased discourse with religious legitimacy, "post-Islamism"

has opened up a productive space where pious sensibilities are able to incorporate a democratic ethos. The growth of such "post-Islamism" out of the anomalies of Islamist politics represents an attempted fusion of elements hitherto often seen as mutually exclusive: religiosity and rights, faith and freedom, Islam and liberty. The daring logic is to turn the underlying principles of Islamism on their head by emphasising rights instead of duties, plurality in place of a singular authoritative voice, ambiguity instead of certainty, historicity rather than fixed scripture, and the future instead of the past. ${ }^{8}$

Accordingly, Muslims have "incorporated into their faith notions of individual rights, tolerance, gender equality, and the separation of religion from the state. By their persistent presence in society, they

6 Fawaz A. Gerges, The Far Enemy: Why Jihad Went Global (Cambridge: Cambridge University Press, 2005).

7 For a lengthier discussion on these typologies see Asef Bayat. "Islamism and Social Movement Theory," in Third World Quarterly 26, 6 (2005): 891-908.

8 Asef Bayat, "Democracy and the Muslim World: The 'Post-Islamist' Turn." March 6, 2009. Last viewed on April 1, 2010 at: http://www.opendemocracy.net/ article/democratising-the-muslim-world 


\section{Islam/ism and Democracy}

compelled religious and political leaders to undertake a paradigmatic 'post-Islamist' shift." Hizbollah, Bayet remarks, "has transcended its exclusivist Islamist platform by adapting to the pluralistic political reality of Lebanon," while Saudi Arabia "has witnessed the emergence (whose fate is uncertain) of a 'post-Wahhabi' trend that seeks some form of compromise between Islam and democracy." In Tajikistan, too, "the Islamic Renaissance Party has been integrated into that country's secular political process," and so has the Justice and Development Party in Morocco. Of course the Justice and Development Party (AKP) that rules in Turkey also stands for "a developed post-Islamic trajectory where pious sensibilities are blended into the secular democratic polity" that "represent some important conscious and reflective adjustments in Islamist politics in the past decade, even if there are significant variations in the depth, scope, and pace of change." 10 The successful revolution in Tunisia, the recent and ongoing uprising in Egypt, and the outrage in Yemen all bear elements of "post-Islamist" discourse and politics. Calls for freedoms of speech and association, democracy, and human rights abound. Indeed, what Bayat calls "post-Islamism" is exceedingly regarded as a legitimate and authentic movement, one that has moved away from rhetoric of the Islamist state towards a democratic state conceived of by way of tolerance and pluralism.

\section{How Muslims Are Democratic}

Where a democratic deficit exists in the Middle East, it is not for lack of want on the part of Middle Eastern denizens. What these states have in common, looking beyond the influence of Islam, are authoritarian governments that rose to power following the withdrawal of colonial powers. The colonial histories and authoritarian aspects of these political economies and political cultures contribute directly to the lack of democracy within these states far more than religious beliefs and practices do. Indeed, a number of studies demonstrate that a majority of Muslim individuals-whether supportive of traditionalist, progressive, or Islamist trends-yearn for and support democratic and liberal practices: gender equality, freedom of speech,

9 Ibid.

10 Ibid. 
and association, to name a few. In much of the Middle East and North Africa, thwarted attempts for democratization and liberalization stem not from culture, but more specifically from a political culture shaped and controlled by the regimes in power. Nonetheless, "postIslamism" appears to be a rising and important movement that poses a direct challenge to authoritarian's political suppression by way of an accessible rights-based discourse. Examining how Muslims are democratic thus provides reasonable conjecture into how "postIslamism" might evolve and manifest in the Middle East in the foreseeable future.

In a recent Gallup World Poll, when asked what they admired most about Muslim societies, most people responded, "people's sincere adherence to Islam." ${ }^{11}$ On the other hand, respondents indicated that "lack of unity, economic and political corruption, and extremism" are what they least admire about the Arab and Muslim region. ${ }^{12} \mathrm{~A}$ majority wanted sharía as a source of legislation, while in Jordan, Egypt, Pakistan, Afghanistan, and Bangladesh majorities wanted sharia as the "only source" of legislation. ${ }^{13}$ Throughout a sample of the Muslim world, the ratio of respondents among men and women who wanted sharia as "the only source" differed considerably, not between the sexes, but across the Muslim world: In Jordan, 54 percent of men and 55 percent of women wanted sharia as the only source of legislation. In Egypt, 70 percent of men and 62 percent of women wanted sharía. In Iran, the figures were 12 percent of men and 14 percent of women and in Indonesia, 14 percent of men and women wanted shar' ia as "the only source" of legislation. ${ }^{14}$ Muslims who want the shari'a as either $a$ or the source of law, or as either $a$ or the guiding reference to the constitution, also had very different views about what that statement entails:

Though the definition of Sharia refers to the principles in the Quran and prophetic traditions, some expect full implementation of classical or medieval Islamic law; others want a more restricted approach, like prohibiting alcohol,

11 John L. Esposito and Dalia Mogahed, Who Speaks for Islam? What A Billion Muslims Really Think (New York: Gallup Press, 2007), 6.

12 Ibid., 34.

13 Ibid., 48.

14 Ibid., 48-9 


\section{Islam/ism and Democracy}

requiring the head of state to be a Muslim, or creating Sharia courts to hear cases involving Muslim family law (marriage, divorce, and inheritance). Still others simply want to ensure that no constitutional law violates the principles and values of Islam, as found in the Quran. ${ }^{15}$

Within the Arab world, studies suggest peoples' overwhelming support for democracy. ${ }^{16}$ The Arab Barometer survey reports 86 percent of respondents who believe that democracy is "the best form of government" and 90 percent who believe that democracy would be a "good" or "very good" system of governance. Additional findings are instructive for analyzing how democracy is valued: 83 percent of respondents believed that reforms should be implemented gradually, 31 percent believed that democracy would negatively affect the economy, and 33 percent believed that democracy is bad for maintaining order. Sixty-two percent of respondents interpreted competition and disagreement among political groups to be positive for their country, while 64 percent believed that that the government should make laws according to the people's wishes.

While in Algeria, Palestine, and Jordan, half of those surveyed indicated that democracy means "freedom to criticize the government" or "to change the government through elections," half stated that democracy amounted to the ability for a government to "provide basic necessities like food, clothing, and shelter for everyone" or to "decrease the income gap between rich and poor." Thus, an "instrumental conception of democracy" characterizes these and other findings about common perceptions on what constitutes democracy. ${ }^{17}$ Democracy, human rights, and good governance appear to be intermixed with concerns for social, economic, and political well-being. When asked to think about problems with governance, 51 percent of respondents in one survey described economic problems like poverty, unemployment and inflation, versus 5 percent who mentioned authoritarianism:

15 Esposito and Mogahed, Who Speaks for Islam? 52.

16 Mark Tessler and Eleanor Gao, "Gauging Arab Support for Democracy," Journal of Democracy 16, 3 (July, 2005): 83-97.

17 Amaney Jamal and Mark Tessler, "Attitudes in the Arab World," Journal of Democracy 19, 1 (Jan, 2008): 98-99. 
One way to read this is that Arab-world majorities support democracy, at least in part, because it promises to make governments more accountable and more attentive to the concerns of ordinary citizens, particularly their economic concerns... it is not so much that democracy is the "right" political system in a conceptual sense, but rather that democracy is a "useful" form of government that has the potential to address many of a country's most pressing needs. ${ }^{18}$

The same study demonstrates a significant variance between Arab Muslim respondents on the relationship between religion and politics. 56 percent of those polled agreed with the statement that "men of religion should have influence over government decisions," while 44 percent disagreed. Of those who agreed that democracy is the best form of government, 54 percent believed that "men of religion should play an important role in government decisions" while 46 percent disagreed. There is thus a clear division amounting to almost half of respondents who support an institutionalized political role of religion, with the other half, who do not. ${ }^{19}$

Even more significantly, an examination of another dimension of how Muslims are democratic reveals common trends despite differences between secular and Islamist or religious adherents. The normative or substantive elements of democracy selected for questioning in the study included respect for political diversity among political leadership, social and/or racial tolerance, and gender equality, measured by questions regarding equal job opportunities and wages. Almost all correspondents demonstrated overwhelming support for democratic values, the importance of political leaders' acceptance of political diversity, and high rates of social and/or racial tolerance. ${ }^{20}$ Finally, equality for job opportunities and wages was considered "moderate to good," generally amounting to positive responses by a two-thirds majority of those polled. ${ }^{21}$

Clearly, political preferences "are not shaped to a significant

18 Ibid.

19 Ibid., 102.

20 Ibid., 103.

21 Ibid. 


\section{Islam/ism and Democracy}

degree by religious orientations or attachments,"22 for "not only does religiosity not lead men and women to be less supportive of democracy, it does not lead them to be more supportive of a political system that incorporates an Islamic dimension." ${ }^{23}$ Studies of support for Islamism and democracy demonstrate that poor socioeconomic conditions are a stronger determinant of support for Islamism than are politico-cultural conditions. ${ }^{24}$

Finally, Gallup Poll respondents indicated that "political freedom and liberty" and "freedom of speech," including the desire for a "fair judicial system" and "citizens enjoying many liberties," are what they admire about the U.S. and the West (despite severe suspicions over the genuineness of U.S. commitments to the democratization of the Muslim world). Across genders and socio-economic classes, Muslim countries "reveal a complex and surprising reality." Indeed, significant majorities of nearly all respondents across a wide sample of nations-95 percent in Burkina Faso, 94 percent in Egypt, 90 percent in Indonesia, and 93 percent in Iran-supported the guarantee of freedom of speech, defined as "allowing all citizens to express their opinion on the political, social, and economic issues of the day," if drafting a new constitution were at hand. ${ }^{25}$ The Gallup Poll therefore demonstrated that the separation of church and state is neither required, nor necessarily desired. ${ }^{26}$ Secular and religious and/ or Islamist adherents alike demonstrate overwhelming respect for liberal and democratic policies. What remains to be seen is precisely the result of the cohabitation or admixture of rights-based discourse and religious discourse that results.

\section{Whither "Post-Islamism" in the Middle East: From "How Democratic} Is Islamism?" to "How Islamism Is Democratic"

Despite continued political repression, especially throughout the Middle East, Islamist parties, where permitted, persevere as democratic participants. There is widespread fear that meaningless

22 Ibid., 108.

23 Ibid., 105.

24 Amaney A. Jamal, "Reassessing Support for Islam and Democracy in the Arab world," American Peace Society 169, 2 (Fall 2006): 51-63.

25 Esposito and Mogahed, Who Speaks for Islam, 47.

26 Ibid., 35. 
ballots will give way to a possible profusion of bullets, or that participation will incite violence and provoke regional instability. However, Islamists have demonstrated great successes at the poles. In addition to garnering considerable repute as both political and social movements throughout the Muslim world that sometimes operate as both militias as well as charities, Islamist movements nonetheless hold prominent posts in which they faithfully represent their constituents in the political arena. Contrary to the supposed dangers that accompany Islamist accessions to power, Islamists' participation should be encouraged and invited, not prevented and feared.

There are real and tangible benefits to including all Islamists in the political process, regardless of their supposed radicalism, that persistently go overlooked. Most Islamists demonstrate genuine intentions to participate in the political system. As such, Islamist victories should be given substantial weight as democratic victories rather than being viewed as potential causes for concern. The problem is that Islamist parties are often illegalized and as such they are not permitted meaningful and inclusive opportunities to contribute to the political system that would develop their political platforms. By extension, Western governments support authoritarian regimes instead of exerting pressure on them to offer incentives for increased Islamist participation.

Where Islamist parties have succeeded, they have been quickly overthrown. What is more, they are overthrown with Western support. The Islamic Salvation Front (FIS), represented by two leaders, one radical and one moderate, was victorious in the first round of Algeria's elections in 1991. But the military intervened before the second round, effectively overthrowing the FIS, and sparking a ten-year civil war that killed over 150,000 people. In the 2006 Palestinian elections, Hamas defeated the secular Fatah party. Shortly thereafter, Hamas seized the Gaza strip and Fatah quickly consolidated its authority over the West Bank. It is important to note that in both cases an Islamist party was elected in legitimate elections that went unrecognized by Western governments. In the case of Hamas, an effective boycott by the U.S. and Israel severely inhibited Hamas' ability to represent and address the needs of its constituents. At present, a three state reality militates against the possibility for a two state solution and the resumption of the peace process.

Limited Islamist victories have been more peacefully accepted, but 


\section{Islam/ism and Democracy}

these strides are simply not enough. Saudi Arabia's 2005 polls showed a strong moderate Islamist victory resulting in Mecca and Medina's municipal councils. A Shi'ite alliance prevailed in Iraq's general elections in late 2005, taking 128 of 275 seats. In Egypt, the Muslim Brotherhood, though outlawed as a political party, ran its candidates as nominal independents and took 20 percent of Parliament's seats. In Turkey, the Islamist Justice and Development Party (AKP) won the November 2002 parliamentary elections with 262 seats-four shy of the plurality required for the AKP to rewrite the constitution.

As a result of these successes, many elections held throughout the Middle East are illegitimate mock elections, as voting tallies readily indicate, that ensure that Islamists are incapable of garnering majority victories. In Egypt, President Mubarak won the 1990 election with 94 percent of the vote, and 88.6 percent in 2005. In Tunisia, President Ben Ali won by 99.4 percent of the vote in 1999 and by 94.5 in $2004 .{ }^{27}$ Though it is difficult to ascertain the extent of popular support for Islamist parties, all indications bespeak a strong legitimacy for Islamist opposition across the board. Whether Tunisia and Egypt come to represent "post-Islamist" victories has yet to be seen. Nonetheless, the unprecedented calls for and strides towards popular rule in both countries indicate that Islamist parties will play an integral role in the politics to come.

A successful tactic that regimes employ to occlude meaningful Islamist practice in the political process is to lead Islamist parties through the lower levels of the political process by a string, thus placing a ceiling on Islamist participation at the higher levels of government and policy-making. This phenomenon, called "semiauthoritarianism" ${ }^{28}$ or "electoral authoritarianism," ${ }^{29}$ is characteristic of Arab regimes that, beginning in the '90s, matched the Islamist turn to electoral candidacy with some limited forms of political liberalization and participation in government. As one scholar notes, "incumbent regimes have decided to allow lawful Islamist parties access to larger spheres of publicity and public action, but without any concomitant access to policy making." Thus, "Islamists from

27 Ibid., 30.

28 Amr Hamzawy and Nathan J. Brown, "A Boon or a Bane for Democracy?" Journal of Democracy 19, 3 (July 2008): 52.

29 Malika Zeghal, "Participation without Power," Journal of Democracy 19, 3 (July, 2008): 31. 
legal parties can sit in parliament (where they have little law-making power) but not the cabinet." 30 The tactic of limited participation and liberalization is an effective measure that gives Islamists and other opposition parties enough of a taste of procedural democracy to ensure that few political debates of any quality or depth take place regarding substantive improvements to the democratic process. This also inhibits the formation of a democratic political culture from coming to fruition.

The uncompetitive and undemocratic nature of these elections lead many to consider the possibility that Islamists are unlikely to win future elections, and that the Hamas accession to power will be the last substantial and legitimate political victory for Islamists for some time to come. ${ }^{31}$ Thus, "semi-authoritarianism" prompts questions about whether Islamists will be able to tolerate these losses, and whether they will resort to bullets where ballots have failed them. But there are good reasons to believe that Islamists will remain faithful to the democratic process. For one, Islamists participate in part to protect themselves from the wrath of the regimes in power. As cases of Muslim Brotherhoods in Jordan and Egypt demonstrate, the media and the public sphere - from mosques to coffee shops - are effective mediums to report political suppression: playing the game in politics allows Islamists to remain in the public eye while mounting support for opposition to the regime in question. ${ }^{32}$

Another reason for Islamists to remain faithful to the democratic process is to be accountable and visible to their constituencies as legitimate political and social movements that seek social justice, political reform, and greater community involvement through the political process. ${ }^{33}$ Islamist platforms reflect these concerns: in Morocco, the PJD's platform is heavily focused on the reform and modernization of the country's economic and social sectors. ${ }^{34}$ In Egypt and Jordan, limited Islamist participation has not amounted to much, since the Jordanian monarchy and the Mubarak regime's ruling elites retain a monopoly of control over how much participation is

30 Ibid, 32 .

31 Hamzawy and Brown, “A Boon or a Bane for Democracy?” 52.

32 Ibid., 54.

33 Ibid., 53.

34 Wittes, "Three Kinds of Movements," 9-10. See also Hamzawy and Brown, "A Boon or a Bane for Democracy?" 54. 


\section{Islam/ism and Democracy}

accorded to the Islamists.

Nonetheless, Islamist parties persevere. In Egypt, the Muslim Brotherhood's recent policy proposal included detailed analyses of political, social, and economic reform "that called for a higher council of religious scholars to evaluate government decisions according to Islamic law," and in Sudan and Yemen, Islamist parties have had to make some notable compromises with some unlikely bedfellows. ${ }^{35}$ Islamist participation therefore appears consistent and stable enough to warrant the consideration that Islamists are genuinely committed to the democratic process. Fears of "one man, one vote, one time" remain unsubstantiated.

\section{Encouraging the "Post-Islamist" Turn}

Despite their commitments to democratic participation, Islamists will be severely disadvantaged, if not stagnantly disenfranchised, through open participation in the current state of the democratic process for as long as Western governments continue to support the suppression of meaningful Islamist participation. For one, Islamists are unable to articulate a succinct and cogent theory of the state, let alone offer a viable theory of democracy or a working conception of citizenship. Islamists are offered few opportunities to contribute to major policy decisions. Their platforms often do not attend to the rights of non-Muslim minorities, women, and tolerance for dissenting secular views. For this reason, most Islamist literature is speculative, and what actually works remains indeterminable. In addition, Islamist claims are very general and ideological so as not to cause friction that could lead to fracture within the Islamist ranks. ${ }^{36}$ But in maintaining a broad strokes approach to governance that is heavily laden with ideology, Islamists approaches risk warding off secular parties now loath to reach across the aisle to explore middle ground. Further fears of frustration over successive losses, political alienation, and the phenomenon of "semi-authoritarian" or "electoral authoritarian" traps may result in violence if democracy does not appear to produce or represent Islamists' interests. Thus, some argue that political participation may actually catalyze political violence.

35 Ibid., 32.

36 Hamzawy and Brown, "A Boon or a Bane for Democracy?" 50, 51. 
After Hamas acceded to power via democratic elections, for example, the seizure of Gaza sparked unprecedented levels of inter-Palestinian rivalry. Islamist violence in Lebanon and Iraq also surfaced despite democratic elections. ${ }^{37}$

In spite of all of these concerns, however, Islamists nonetheless share some "respect for the institutional framework of the state in which they operate; acceptance of plurality as a legitimate mode of political existence; and a gradual retreat from ideological debates in favour of a growing concentration on pragmatic agendas that are primarily concerned with influencing public policies." ${ }^{38}$ In Morocco, the Islamist PJD party's recent social and economic policy proposals largely cohere with the state's justifications for the Islamic legitimacy of the state to monitor and regulate religious institutions. ${ }^{39}$ In a country whose monarch is constitutionally defined as the "Commander of the Faithful," political contention over how to interpret these justifications and policies are an avenue to greater participation in the political system that has led to some measure of pluralism. By acquiescing to the monarch's claim over Islamic legitimacy, political discussions that are permitted to take place advance claims about what constitutes Islamic legitimacy in the first place, leaving open the possibility for meaningful opportunities for policy formation and substantive conversations about democratic or political norms of governance.

Thus, although political violence remains a concern, there are scant reasons to think that democratizing states facilitate political violence or that Islamists will discard ballots for bullets if greater political liberalization is seen to be on the horizon. Islamists are doubtless being taken through the democratic process at arm's length. But more normalized Islamist participation could mean more detailed and realistic policy proposals. Likewise, more exposure and experience with electoral competitiveness and political normalization translates into a higher likelihood of the emergence of a pluralistic democratic political culture from below.

Whether Islamism supports democratic politics will greatly depend on the extent to which Islamists are permitted meaningful and inclusive participation in the political process. For as long as authoritarians and Western patrons suppress democratic movements,

37 Ibid., 51.

38 Ibid.

39 Zeghal, "Participation without Power," 34. 


\section{Islam/ism and Democracy}

fix elections, and stagnate voices of opposition from Islamist or secular opponents alike, indigenous democratic models are incapable of even being tested. As such, indigenous democratic political cultures are incapable of realization.

It is high time to discard the compatibility problem of Islam/ism and democracy. Instead, and especially in light of recent popular uprisings in Egypt and Yemen that have followed from the overthrow of the Ben Ali regime in Tunisia, Western pundits, political scientists and politicians should turn their attention to the many and diverse ways in which "post-Islamism" might be encouraged and developed, whether by exerting pressure on authoritarian governments to allow for greater political liberalization, reaching out to Islamist parties for cross-cultural democratic dialogue, or democratizing the definition of democracy to accept that Western liberalism is not the only form of democracy. Indeed, by virtue of its definition democracy - "freedom and equality," rule of the people," and so on-should be accepted in its multiplicity and pluralism as it is differently understood within and across cultures. Though democracy has yet to take definitive form in the Middle East, whether as theory or in praxis, elsewhere throughout the Muslim world democratic politics is indeed the norm. For the Middle East, democracy lies on the horizon. Whatever shape democracies may take, whether Islamist, "post-Islamist," or otherwise, by virtue of democracy qua democracy, it behooves Western regimes to support legitimate indigenous expressions, whether they compete or contravene liberal or neo-liberal Western models or not.

\section{Bibliography}

Abdul Hakim, Khalifa. "Islam and Democracy." Last viewed on February 6, 2010 at http://muslim-canada.org/ch19hakim.html.

Abootalebi, Ali R. "Islam, Islamists, and Democracy." Middle East Review of International Affairs 3, 1 (March 1999). Last viewed on February 6, 2010 at http://meria.idc.ac.il/journal/1999/ issuel/jv3nla2.html.

An-Na’im, Abdullahi Ahmed. Toward an Islamic Reformation: Civil Liberties, Human Rights and International Law. Syracuse, NY: 
Syracuse University Press, 1990.

Bayat, Asef. "Islamism and Social Movement Theory." Third World Quarterly, 26:6 (2005): 891-908.

."Democracy and the Muslim World: the 'Post-Islamist Turn." March 6, 2009. Last viewed on April 1, 2010 at http:// www.opendemocracy.net/article/democratising-the-muslimworld

Esposito, John L., and Mogahed, Dalia. Who Speaks for Islam? What A Billion Muslims Really Think. New York: Gallup Press, 2007.

Euben, Roxanne L., and Zaman, Muhammad Qasim, eds. Princeton Readings in Islamist Thought. Princeton: Princeton University Press, 2009.

Gerges, Fawaz A. The Far Enemy: Why Jihad Went Global. Cambridge: Cambridge University Press, 2005.

Hamzawy, Amr, and Brown, Nathan J. "A Boon or a Bane for Democracy?” Journal of Democracy 19, 3 (July 2008): 49-54.

Jamal, Amaney A. "Reassessing Support for Islam and Democracy in the Arab World." American Peace Society 169, 2 (Fall 2006): $51-63$.

Jamal, Amaney A., and Tessler, Mark. "Attitudes in the Arab World." Journal of Democracy 19, 1 (Jan. 2008): 97-110.

Tessler, Mark, and Gao, Eleanor. "Gauging Arab Support for Democracy.” Journal of Democracy 16, 3 (July 2005): 83-97.

Wittes, Tamara Coffman. "Three Kinds of Movements." Journal of Democracy 19, 3 (2008): 7-12.

Zeghal, Malika. "Participation without Power." Journal of Democracy 19, 3 (July, 2008): 31-36. 